\author{
ACTA MYCOLOGICA \\ Vol. 47 (2): 203-212 \\ 2012
}

\title{
Agonimia species and other rare lichens in Central Poland
}

\author{
ANNA ŁUBEK \\ Institute of Biology, Jan Kochanowski University, Świętokrzyska 15A \\ PL-25-406 Kielce, anna.lubek@ujk.edu.pl
}

Łubek A.: Agonimia species and other rare lichens in Central Poland. Acta Mycol. 47 (2): 203-212, 2012.

Eight lichen species are presented. Four of them: Agonimia flabelliformis, A. opuntiella, A. tristicula and Micarea adnata are new to Central Poland. Caloplaca cerina var. chloroleuca, Micarea hedlundii and Porina leptalea are very rare in the Świętokrzyskie Mts and in Central Poland.

Key words: Ascomycota, lichen distribution, protected areas

\section{INTRODUCTION}

Although the Świętokrzyskie Mts have relatively well known lichen biota, recent explorations provide new species. As a result of these investigations eight species rarely reported from Poland have been found, including Agonimia flabelliformis, $A$. opuntiella, A. tristicula, Bacidia sulphurella, Caloplaca cerina var. chloroleuca, Micarea adnata, M. hedlundii and Porina leptalea. So far four of them were not recorded in Central Poland.

The species of the genus Agonimia deserve special attention. So far, seven species of this genus have been identified in Poland (Tab. 1): Agonimia allobata, $A$. gelatinosa, $A$. opuntiella, $A$. repleta, $A$. tristicula, $A$. vouauxii and recently described A. flabelliformis. Most of them occur mainly in mountain areas and in northern part of Poland. Agonimia allobata, corticolous species or found also on plant debris, has been reported at several sites in Śnieżnik Massif and Bialskie Mts (Szczepańska 2008), Pieniny Mts (Kiszka 2000), Gorce Mts (Czarnota et al. 2005), Borecka Forest (Cieśliński 2003) and Mazovia region (Kubiak 2009). Agonimia gelatinosa is terricolous, on calcareous soil, muscicolous and grows also on plant debris. This rare species in Poland is known from Kujawy area (Ceynowa-Giełdon 2001), Gorce Mts (Czarnota 2000) and Sudety Mts (Kossowska 2008). Agonimia opuntiella in Poland is 
known mostly from mountain regions, the Eastern and Western Carpathians (Kiszka 1997; Bielczyk 2003; Fałtynowicz 2003) where it grows on calcareous soil and on bryophytes in sunny places. Agonimia repleta is more frequent species in this country. It is saxicolous, muscicolous and corticolous species found usually in wet forests on deciduous trees: Acer, Alnus, Fagus and Ulmus. It is reported for example from the north-eastern part of the country (Czyżewska et al. 2001; Cieśliński 2003), from its central part (Lubek 2012a, b) and from its south part (Czarnota, Coppins 2000; Kiszka, Kościelniak 2001; Bielczyk et al. 2004). Agonimia tristicula grows on calcareous soil, on bryophytes and on plant debris in open habitats beeing quite common in mountain areas, the Western and Eastern Tatry Mts and Pieniny Mts. Only locality in northern part of Poland, in the Mazurian Lake District is also known (Olech, Kiszka 1999). Agonimia vouauxii in this country is reported from anthropogenic habitats from Olkusz region (Bielczyk 2012).

The main aim of this work is to provide the most up-to-date information for the new and rare species in Central Poland, especially for those recently described.

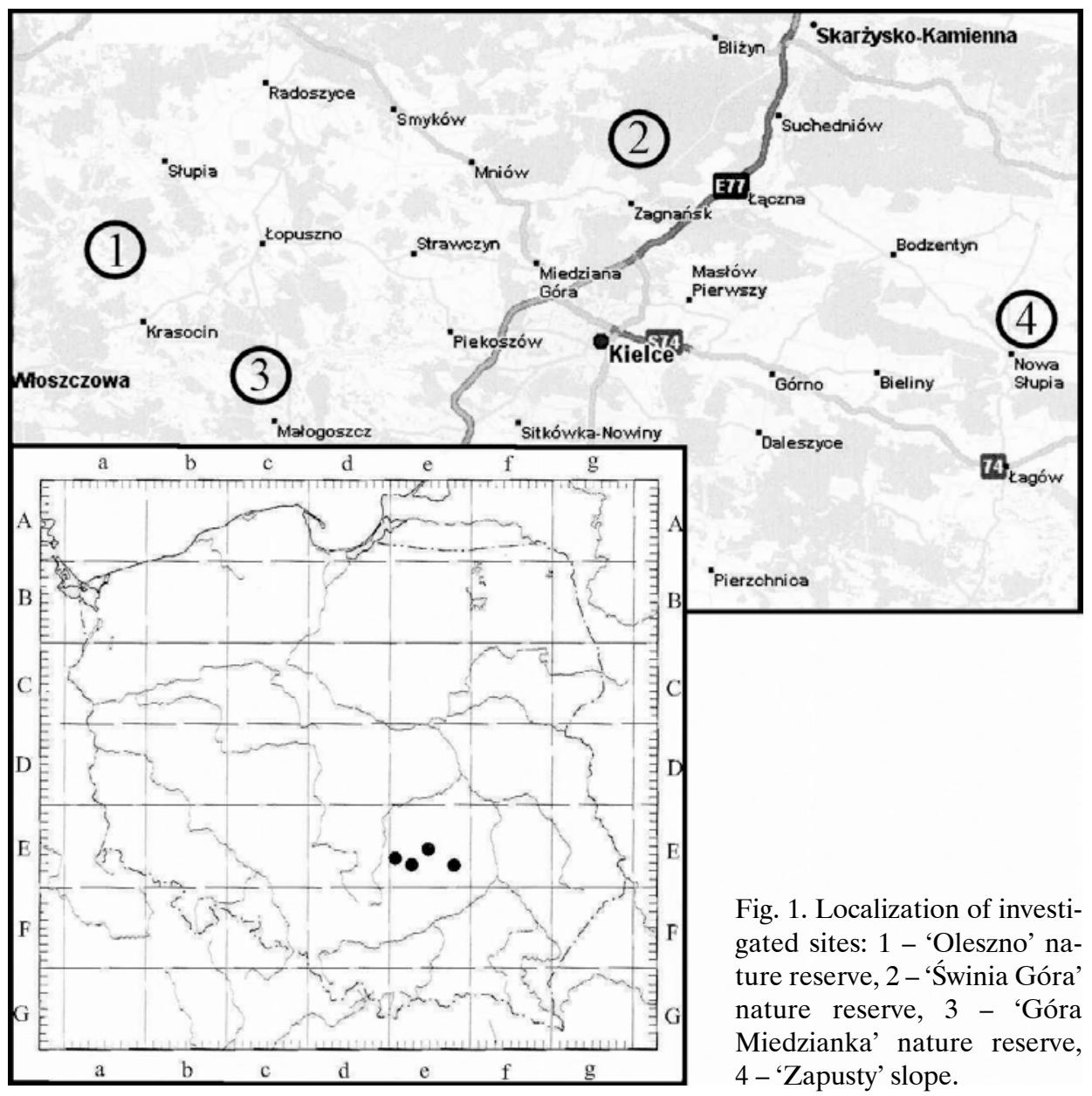




\section{MATERIAL AND METHODS}

Lichens were collected in 2001, 2007, 2010 and 2011 at four sites in the Świętokrzyskie Mts and in their immediate vicinity (Fig. 1): in 'Góra Miedzianka' nature reserve in the Chęcińsko-Kielecki Landscape Park, in 'Zapusty' slope in the Świętokrzyski National Park, in 'Świnia Góra' nature reserve in the Suchedniowsko-Oblegorski Landscape Park and in 'Oleszno' nature reserve in the Przedborski Landscape Park, located in squares Ee 54, 60, 72, 77 of ATPOL grid square system (Cieśliński, Fałtynowicz 1993). The material was analyzed with standard morphological and anatomical methods.

\section{RESULTS AND DISCUSSION}

The nomenclature of the species follows Smith et al. (2009) with exception of $A g O-$ nimia flabelliformis - Guzow-Krzemińska et al. (2012). Characteristics of Agonimia representatives (Tab. 1) according to Smith et al. (2009), Guzow-Krzemińska et al. (2012) and Sérusiaux et al. (1999). The specimens are deposited in the herbarium of the Jan Kochanowski University (KTC).

Abbreviations: ŚNP - Świętokrzyski National Park; S-OLP - Suchedniowsko-Oblęgorski Landscape Park; PrzLP - Przedborski Landscape Park, Ch-KLP - Chęcińsko-Kielecki Landscape Park.

Agonimia flabelliformis Halda, Czarnota \& Guzow-Krzemińska

This species was described from the Czech Republic, and mentioned additionally from Germany and Great Britain (Guzow-Krzemińska et al. 2012). In Poland it is only known form Tatry Mts (Czarnota 2012). Its site in 'Oleszno' nature reserve is the first in Central Poland.

Species is characterized by a small flabelliform thallus and globose perithecia with 8-spored asci. For the full description of the species see Guzow-Krzemińska et al. (2012). A . flabelliformis resembles $A$. allobata, from which it differs only in the presence of flabelliform aggregations of goniocysts (Guzow-Krzemińska et al. 2012). Agonimia flabelliformis prefers rather humid, shaded, mossy places within deciduous forests where usually grows on bark and on soil. The collection from the Przedborski Landscape Park was found on the trunk of Fraxinus excelsior with the company of Bacidia pycnidiata and Bacidina sulphurella. It has a dull-green minutely flabelliform squamulose to coralloid thallus, a few grey-brown perithecia which are superficial or partially immersed between squamules.

Specimen eXAmined. ATPOL grid square Ee 60 - PrzLP, near the 'Oleszno' nature reserve, forest section no 79, 50 56'42”N/ $20^{\circ} 06^{\prime} 17^{\prime}$ 'E, on a trunk of Fraxinus excelsior, 7 Feb. 2008.

Agonimia opuntiella (Buschardt \& Poelt) Vĕzda

Syn. Phaeophyscia opuntiella (Buschardt \& Poelt) Hafellner

The species occur in many countries in Europe such as: Belgium, Luxembourg, France (Diederich et al. 2011), Great Britain and Ireland (Smith et al. 2009), the 
Czech Republic (Vězda, Liška 1999), Switzerland (Clerc, Truong 2010) and Germany (Wirth et al. 2010).

Agonimia opuntiella deserves special attention because of the perithecia which are formed very rarely. This species is characterized by greenish-grey to brownish minutely squamulous thallus (lobes up to $4 \mathrm{~mm}$ width) with marginal ellipsoid to subglobose blastidia. Surface of thallus has minute hyaline hairs. Perithecia are formed rarely or if so they are small pyriform, black and rugose $(0.2-0.5 \times 0.2-0.4$ $\mathrm{mm}$ ) on the lobe bases (Aptroot et al. 2008; Aptroot 2011). Two densely muriform ascospores, $40-70 \times 20-30 \mu \mathrm{m}$, are produced in asci.

So far, in Poland ascocarps of Agonimia opuntiella have not been reported (Kiszka 1997). The collection from the Chęcińsko-Kielecki Landscape Park has no perithecia indeed, but the specimen from Świętokrzyski National Park produces a few small, inconspicuous black perithecia, located on the lobe base. They are sometimes partially hidden by adjacent squamules and blend with dark ground decaying bryophytes: more visible when wet. Spores of Agonimia opuntiella, similarly to $A$. tristicula, are produced per two in ascus, but they are much smaller. Ascospores of $A$. opuntiella from the Świętokrzyski National Park have dimensions of 60-63×26-28 $\mu \mathrm{m}$ and in $A$. tristicula, which was found in the Chęcińsko-Kielecki Landscape Park, they reach 72-96×36-48 $\mu \mathrm{m}$.

Agonimia opuntiella from the Swiętokrzyski National Park was already published, however under the name Phaeophyscia kairamoi - young thallus in the initial stage of growth was difficult to determine (Lubek 2003; Łubek, Cieśliński 2004; Łubek 2007). After a careful examination of the specimen, a few small perithecia have been found, thus now there is no doubt that it represents $A$. opuntiella. These two species are similar because of the presence of marginal blastidia and tiny hyaline hairs on the surface of thallus. Because of this mistake, Ph. kairamoi should be deleted from the list of lichens of the Świętokrzyskie Mts. Here $A$. opuntiella is reported also as new to Central Poland.

SPECIMENS EXAMINED. ATPOL grid square Ee 72 - Ch-KLP, 'Góra Miedzianka' nature reserve, on bryophytes growing on calcareous rocks, Sexposure, 50 50’44”N/20²'46”'E, 8 Oct. 2011, leg. B. Słowińska (KTC); Ee 77 - ŚNP, 'Zapusty' slope, on bryophytes

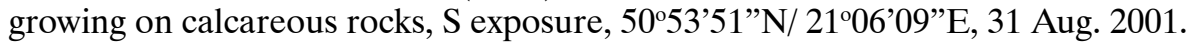

Agonimia tristicula (Nyl.) Zahlbr

Syn. Verrucaria tristicula Nyl.

This species occurs in many countries in Europe such as: Belgium, Luxembourg, France (Diederich et al. 2011), the Czech Republic (Vězda, Liška 1999), Estonia (Randlane, Saag 1999), Sweden and Norway (Santesson 1993), Switzerland (Clerc, Truong 2010) and Germany (Wirth et al. 2010).

Agonimia tristicula is reported here as new to the Świętokrzyskie Mts and Central Poland. It was found in the Chęcińsko-Kielecki Landscape Park, where grew on bryophytes on calcareous soil. It characterizes by dull to pale green or brown minutely squamulose thallus, which often forms small, aggregate patches. Perithecia are frequent, fairly big, barrel-shaped, black, matt and plicate-rugose. Asci produce two spores: $72-96 \times 36-48 \mu \mathrm{m}$.

SPECIMEN EXAMINED. ATPOL grid square Ee 72 - Ch-KLP, 'Góra Miedzianka' nature reserve, on bryophytes growing on calcareous rocks, $\mathrm{S}$ exposure, $50^{\circ} 50^{\prime} 44^{\prime} \mathrm{N} / 20^{\circ} 21^{\prime} 46^{\prime \prime} \mathrm{E}, 8$ Oct. 2011, leg. B. Słowińska. 
Bacidina sulphurella (Samp.) M. Hauck \& V. Wirth

Syn. Bacidia sulphurella Samp.

In Europe this species is known from many countries: Belgium, Luxembourg, France (Diederich et al. 2011), Great Britain and Ireland (Smith et al. 2009), Switzerland (Clerc, Truong 2010) and Germany (Wirth et al. 2010). In Poland Bacidina sulphurella is known for example from: Góry Sowie Mts and Puszcza Knyszyńska Forest (Brand et al. 2009), Gorce Mts (Czarnota 2010) and Pogórze Wiśnickie foothills (Śliwa 2010). In Central Poland the species was reported from few localities in 'Las Bielański' forest reserve (Kubiak et al. 2010) and Wzniesienia Lódzkie Landscape Park (Hachułka 2011). It is surely more common species but formerly many times determined as Bacidina arnoldiana (see Czarnota 2010).

Bacidina sulphurella is characterized by finely granular, green thallus and white, pale to greyish coloured, usually present pycnidia, producing filiform, at least in one end strongly hooked, 0-3 septate conidia (Brand et al. 2009). The specimen from the 'Oleszno' nature reserve has few typical pycnidia and well developed thallus. The species grow in the company of Agonimia flabelliformis.

Specimen eXAmined. ATPOL grid square Ee 60 - PrzLP, near 'Oleszno' nature reserve, forest section no 79, on a trunk of Fraxinus excelsior, 50 56 '42”N/ $20^{\circ} 06$ '17'E, 7 Feb. 2008, (KTC, with Agonimia flabelliformis and Bacidia pycnidiata), det. P. Czarnota.

Caloplaca cerina var. chloroleuca (Sm.) Th. Fr.

Syn. Caloplaca cerina var. muscorum A. Massal.

This is a very rare species in Poland (Fałtynowicz 2003). It is known primarily from mountain areas: Sudety Mts, Western Carpathians Mts and Wyżyna ŚląskoKrakowska Upland (Fałtynowicz 2003) as well as from the north-eastern part of Poland (Cieśliński 2003) where grows on plant debris, soil or on mosses in xerothermic grasslands and gravel pits. In Central Poland Caloplaca cerina var. chloroleuca is known from Zelejowa Mt. near 'Skorocie' nature reserve and near Lasocin village in the Świętokrzyskie Mts (Cieśliński 1979).

Specimen of $C$. cerina var. chloroleuca collected in the Chęcińsko-Kielecki Landscape Park is small and has a scurfy, green-grey thallus, and a few sessile apothecia with thick, grey thalline margin and orange-yellow disc.

SPECIMEN EXAMINED. ATPOL grid square Ee 72 - Ch-KLP, 'Góra Miedzianka' nature reserve, on bryophytes growing on calcareous rocks, $\mathrm{S}$ exposure, 5050’44”N/20²1'46” E, 8 Oct. 2011, leg. B. Słowińska.

\section{Micarea adnata Coppins}

This is the first information on the occurrence of this species in the Świętokrzyskie Mts and in Central Poland. In this country it is known only from two mountain regions: Karkonosze Mts (Kossowska 2001) and Western Beskidy Mts (Czarnota 2007). In Europe this species is widespread; known from the Czech Republic (Vězda, Liška 1999), Sweden (Santesson 1993), Switzerland (Clerc, Truong 2010), Germany (Wirth et al. 2010) and other countries (see Czarnota 2007).

Micarea adnata is easily to identify owing to its characteristic apothecia and sporodochia (Czarnota 2007). It grows on the bark of coniferous trees, on wood or decaying stumps. The specimen mentioned here has numerous straw-coloured apothecia, which are immarginate or sometimes surrounded with distinctly visible white 


\begin{tabular}{|c|c|c|c|c|c|c|c|}
\hline \multirow{2}{*}{\multicolumn{2}{|c|}{ 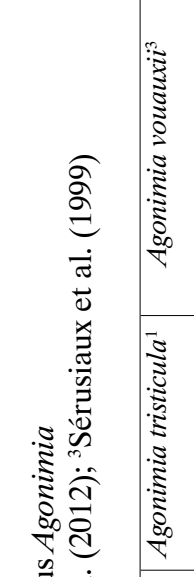 }} & 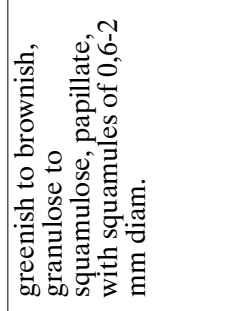 & 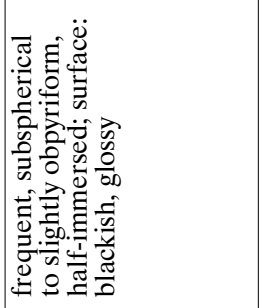 & 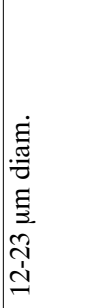 & 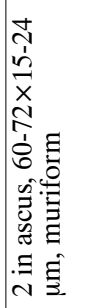 & 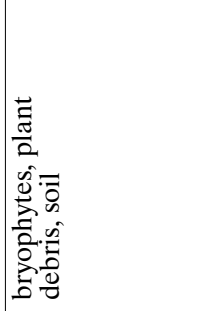 & 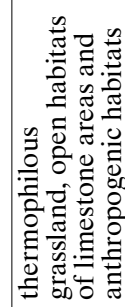 \\
\hline & & 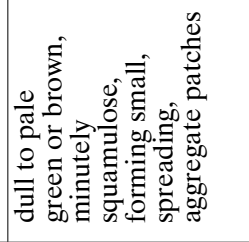 & 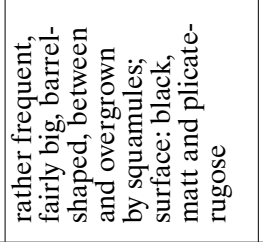 & 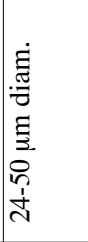 & 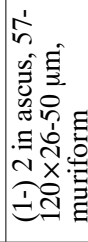 & 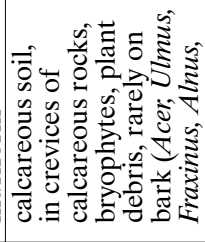 & 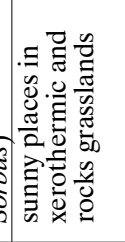 \\
\hline 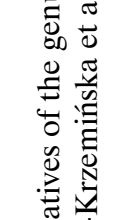 & 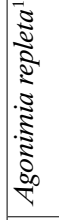 & 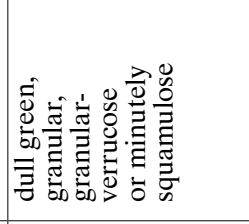 & 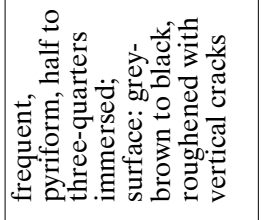 & 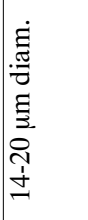 & 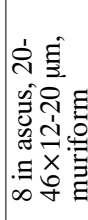 & 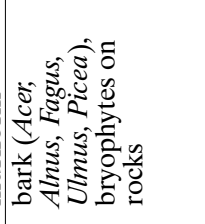 & 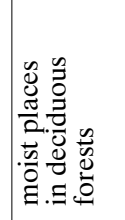 \\
\hline 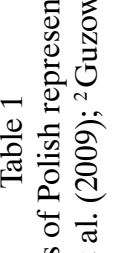 & 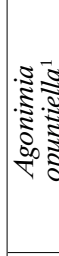 & 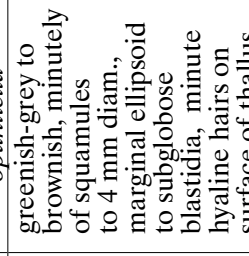 & 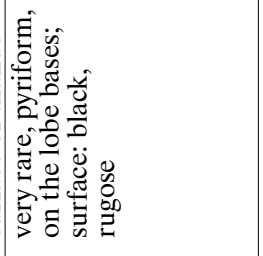 & 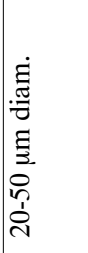 & 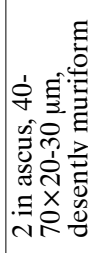 & & 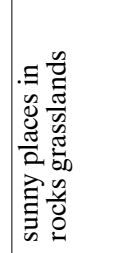 \\
\hline 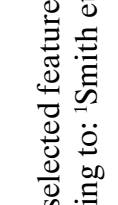 & 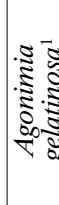 & 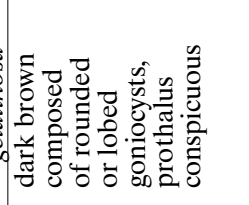 & 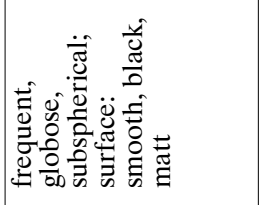 & 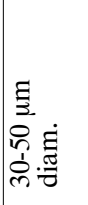 & 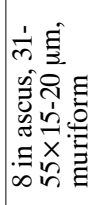 & 总 & 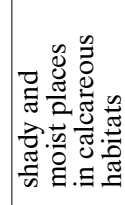 \\
\hline 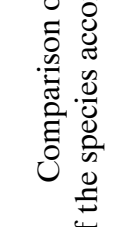 & 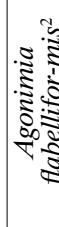 & 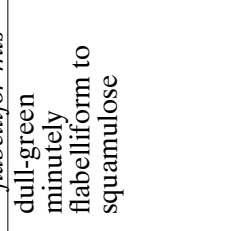 & 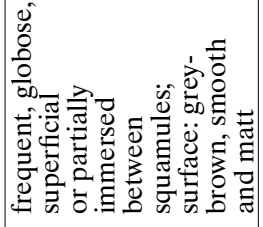 & 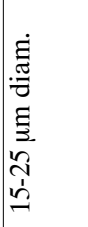 & 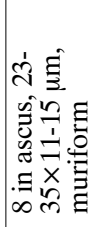 & 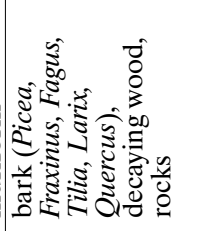 & 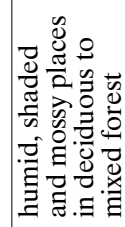 \\
\hline 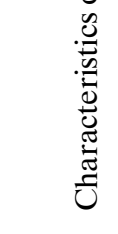 & 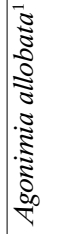 & 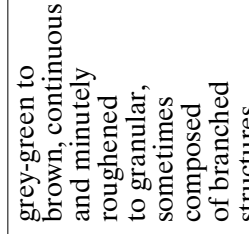 & 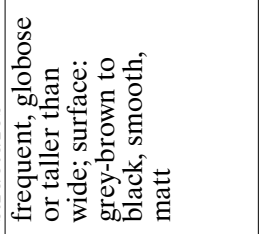 & 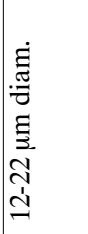 & 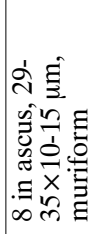 & 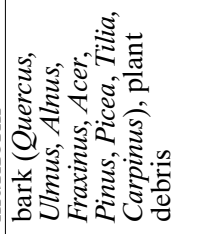 & 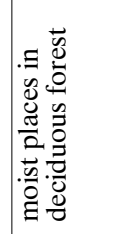 \\
\hline & 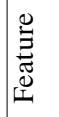 & 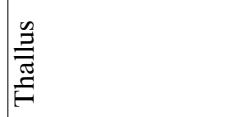 & 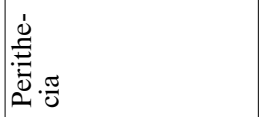 & 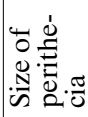 & $\tilde{n}$ & 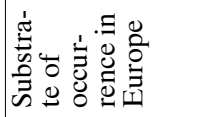 & 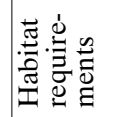 \\
\hline
\end{tabular}


rim. Convex or globose sporodochia, resembling small apothecia, are numerous and produces macroconidia $8-9 \times 2-3 \mu \mathrm{m}$.

Due to the specific habitat requirements and its occurrence only in natural forests, $M$. adnata is proposed to be regarded as an indicator of ecological continuity for woodlands of lower mountain belt in Central Europe (Czarnota 2007). Also the site in Central Poland is located in such natural forest. 'Swinia Góra' nature reserve is one of the oldest in the Świętokrzyskie Mts, being remnants of the Puszcza Świętokrzyska Forest. SPECIMEN EXAMINED. ATPOL grid square Ee 54 - S-OLP, 'Świnia Góra' nature reserve, on lignum, 51 ${ }^{\circ} 03^{\prime} 16^{\prime \prime} \mathrm{N} / 20^{\circ} 41^{\prime} 58^{\prime \prime} \mathrm{E}, 10$ Nov. 2010.

\section{Micarea hedlundii Coppins}

In Poland it is reported mainly from Eastern and Southern Poland (Czarnota 2007). In Central Poland Micarea hedlundii was already recorded in the Świętokrzyski National Park (Lubek 2003), in the 'Spała' nature reserve and the Puszcza Kozienicka Forest (Czyżewska et al. 2005; Czarnota 2007).

Characteristic feature of this species are pycnidia coated with white tomentum and orange droplets of an oil substance in goniocysts which reacting $\mathrm{K}+$ purpleviolet. Specimen examined from the Suchedniowsko-Oblęgorski Landscape Park has only pycnidia.

SPECIMEN EXAMINED. ATPOL grid square Ee 54 - S-OLP, 'Świnia Góra' nature reserve, on lignum, 51 ${ }^{\circ} 03^{\prime} 16^{\prime} \mathrm{N} / 20^{\circ} 41^{\prime} 58^{\prime \prime} \mathrm{E}, 10$ Nov. 2010.

Porina leptalea (Durieu \& Mont.) A. L. Sm.

This species is known from many European countries, for example: Belgium, Luxembourg, France (Diederich et al. 2011), Switzerland (Clerc, Truong 2010), Germany (Wirth et al. 2010) and the Czech Republic (Vězda, Liška 1999). In Poland is a rare species found in mountain areas: Gorce Mts (Czarnota 2000), Pieniny Mts (Kiszka 2000), Bieszczady Niskie Mts (Kościelniak 2004) and Sudety Mts (Szczepańska 2007). In the Świętokrzyskie Mts it seems to be also rare. Its first four sites in the Świętokrzyski National Park have already been published (Lubek 2003) and here is presented additional locality of this species in this region.

Specimen examined has dull orange-brown to red-brown perithecia, hemispherical to subglobose $0,1-0,4 \mathrm{~mm}$ diam., which are one quarter to one half immersed in thin grey-green thallus. Ascospores are fusiform-cylindrical or oblong, 3-septate and $15-25 \times 2-4 \mu \mathrm{m}$. It has also orange pycnidia with narrowly ellipsoid conidia 3-4,5 $\times 1 \mu \mathrm{m}$. SPECIMEn EXAmined. ATPOL grid square Ee 54 - S-OLP, 'Świnia Góra' nature reserve, on trunk of Fagus sylvatica, 51'03’16”N/ 2041'58”'E, 10 Nov. 2010.

\section{CONCLUSIONS}

The Świętokrzyskie Mts appear to be very interesting from lichenological point of view. The specific topography, various geology and often natural vegetation, make appropriate conditions for lichens both widespread and of narrow ecological-scale. Particularly noteworthy are the species occurring in Poland only in mountain areas, including Agonimia opuntiella, Micarea adnata and Porina leptalea. 
Among the studied areas noteworthy are 'Oleszno' nature reserve in the Przedborski-Landscape Park and 'Świnia Góra' nature reserve in the SuchedniowskoOblęgorski Landscape Park. The natural character of forests in the 'Oleszno' nature reserve has already been underlined few times by the presence of very rare epiphytic lichens in Poland (Lubek 2009a, b). In this paper two next lichen-forming fungi are interesting: Agonimia flabelliformis and Bacidina sulphurella. First one because up to now it was found in Poland only once, and the second species because its real distribution in Europe is still poorly known.

'Świnia Góra' nature reserve appears to be also noteworthy protected area owing to a large amount of dead wood inhabited by lignicolous lichens, such as: Micarea adnata and $M$. hedlundii.

Acknowledgements. I would like to thank Professor Krystyna Czyżewska (University of Łódź) for many valuable suggestions received during the preparation of the manuscript, Professor Paweł Czarnota (Scientific Laboratory, the Gorce National Park) for determining Bacidia sulphurella and confirmed the determination of Agonimia flabelliformis and Micarea adnata, and Beata Słowińska for common filed works. Sincere thanks are also addressed to anonymous reviewers for considerable remarks on the text.

\section{REFERENCES}

Aptroot A. 2011. New lichen records from Australia 73. Agonimia opuntiella. Australasian Lichenology 68: 3. http://www.nhm.uio.no/botanisk/lav/RLL/AL/AL68.pdf

Aptroot A., Lücking R., Sipman H.J.M., Umańa L., Chaves J.L. 2008. Pyrenocarpous lichens with bitunicate asci. A first assessment of the lichen biodiversity inventory in Costa Rica. Bibliotheca Lichenologica 97: 1-162. http://www.inbio.ac.cr/papers/liquenes/pdf/Pyrenocarpos_2008.pdf

Bielczyk U. 2003. The lichens and allied fungi of the Polish Western Carpathians. (In:) U. Bielczyk (ed.). The lichens and allied fungi of the Polish Carpathians. An annotated checklist. W. Szafer Institute of Botany, Polish Academy of Sciences, Kraków: 23-232.

Bielczyk U. 2012. Lichens of zinc-lead post-mining areas in the Olkusz region - state of preservation, threats and needs for protection. (In:) L. Lipnicki (ed.). Lichen protection - Protected lichen species. Sonar Literacki, Gorzów Wlkp.: 119-128.

Bielczyk U., Lackovičová A., Farkas E.E., Lőkös L., Liška J., Breuss O., Kondratyuk S. Ya. 2004. Checklist of lichens of the Western Carpathians. W. Szafer Institute of Botany, Polish Academy of Sciences, Kraków.

Brand M., Coppins B., van den Boom P.P.G., Sérusiaux E. 2009. Further data on the lichen genus Bacidia s. 1. in the Canary Islands and Western Europe, with descriptions of two new species. Bibliotheca Lichenologica 99: 81-92.

Ceynowa-Giełdon M. 2001. Kalcyfilne porosty naziemne na Kujawach. Ed. University of Nicolaus Copernicus, Toruń, 43 pp.

Cieśliński S. 1979. Udział oraz rola diagnostyczna porostów naziemnych w zbiorowiskach roślin naczyniowych Wyżyny Kielecko-Sandomierskiej i jej pobrzeży. Wyd. WSP w Kielcach, Kielce, 250 pp.

Cieśliński S. 2003. Atlas rozmieszczenia porostów (Lichenes) w Polsce Północno-Wschodniej. Phytocoenosis 15 (N.S.), Suppl. Cartogr. Geobot. 15: 1-426.

Cieśliński S., Fałtynowicz W. 1993. Note from editors. (In:) S. Cieśliński, W. Fałtynowicz (ed.). Atlas of the geographical distribution of lichens in Poland. 1. W. Szafer Institute of Botany, Polish Academy of Sciences, Kraków: 8-9.

Clerc P., Truong C. 2010. Catalogue des lichens de Suisse. http:/www.ville-ge.ch/musinfo/bd/cjb/cataloguelichen

Czarnota P. 2000. Porosty Gorczańskiego Parku Narodowego. Część I. Wykaz i rozmieszczenie gatunków. Parki nar. Rez. przyr. 19 (1): 3-73.

Czarnota P. 2007. The lichen genus Micarea (Lecanorales, Ascomycota) in Poland. Polish Botanical Studies 23: 1-199. 
Czarnota P. 2010. Krytyczna lista porostów i grzybów naporostowych Gorców. Ochrona Beskidów Zachodnich 3: 55-78.

Czarnota P. 2012. New records of lichenized and lichenicolous fungi from Tatra National Park (W Carpathian). (In:) L. Lipnicki (ed.). Lichen protection - Protected lichen species. Sonar Literacki, Gorzów Wlkp.: 287-300.

Czarnota P., Coppins B.J. 2000. A new species of Agonimia and some interesting lichens from Gorce Mts (Western Beskidy Mts) new to Poland. Graphis Scripta 11: 56-60.

Czarnota P., Glanc K., Nowak J. 2005. Materiały do bioty porostów Gorców ze zbiorów Herbarium Instituti Botanici Polskiej Akademii Nauk w Krakowie. Fragm. Flor. Geobot. Polonica 12 (2): 327-370.

Czyżewska K., Motiejũnaité J., Cieśliński S. 2001. Species of lichenized and allied fungi new to Białowieża Large Forest (NE Poland). Acta Mycol. 36 (1): 13-19.

Czyżewska K., Motiejūnaite J., Cieśliński S. 2005. New and noteworthy species of lichens and allied fungi from North-Eastern Poland. Acta Mycol. 40 (2): 277-291.

Diederich P., Ertz D., Stapper N., Sérusiaux E., van den Broeck D., van den Boom P., Ries C. 2011. The lichens and lichenicolous fungi of Belgium, Luxembourg and northern France. http://www.lichenology.info

Fałtynowicz W. 2003. The lichens, lichenicolous and allied fungi of Poland. An annotated checklist. W. Szafer Institute of Botany, Polish Academy of Sciences, Kraków, 435 pp.

Guzow-Krzemińska B., Halada J.P., Czarnota P. 2012. A new Agonimia with flabelliform thallus from Europe. The Lichenologist 44 (1): 1-12.

Hachułka M. 2011. Freshwater lichens on submerged stones and alder roots in the Polish lowland. Acta Mycol. 46 (2): 233-244.

Kiszka J. 1997. Nowe dla Pienin gatunki porostów. I. Fragm. Flor. Geobot. Polonica 4: 325-328.

Kiszka J. 2000. Nowe dla Pienin gatunki porostów. II. Fragm. Flor. Geobot. Polonica 7: 277-279.

Kiszka J., Kościelniak R. 2001. Nowe i rzadkie gatunki porostów Lichenes w Bieszczadzkim Parku Narodowym i jego otulinie. III. Roczniki Bieszczadzkie 9: 27-32.

Kossowska M. 2001. Ostoja porostów epifitycznych na jodłach (Abies alba) w Wąwozie Szklarki (Karkonosze). In: Botanika w dobie biologii molekularnej. Materiały sesji i sympozjów 52. Zjazdu Polskiego Towarzystwa Botanicznego, Wydawnictwo Poznańskie, Poznań, p. 176.

Kossowska M. 2008. Lichens growing on calcareous rocks in the Polish part of he Sudety Mountins. Acta Bot. Siles., Monogr. 3: 1-108.

Kościelniak R. 2004. Porosty (Lichenes) Bieszczadów Niskich. Fragm. Flor. Geobot. Polonica, Suppl. 5: 3-164.

Kubiak D. 2009. Porosty rezerwatu „Dziektarzewo“. Parki nar. Rez Przyr. 28 (2): 45-55.

Kubiak D., Wrzosek M., Zaniewski P. 2010. Materiały do bioty porostów i grzybów naporostowych rezerwatu „Las Bielański” w Warszawie. Parki nar. Rez. Przyr. 29 (3): 3-15.

Łubek A. 2003. Noteworthy lichen species in Poland collected in the Świętokrzyski National Park. Acta Mycol. 38 (1/2): 137-147.

Łubek A. 2007. Antropogeniczne przemiany bioty porostów Świętokrzyskiego Parku Narodowego i otuliny. Fragm. Flor. Geobot. Polonica, Suppl. 10: 3-94.

Łubek A. 2009a. Jamesiella anastomosans, a lichen species new to Poland. Polish Bot. J. 54 (1): 125-127.

Łubek A. 2009b. New records of lichens from Polish uplands. Acta Mycol. 44 (2): 275-282.

Łubek A. 2012a. The lichen biota of „Skałki Piekło pod Niekłaniem“ Nature Reserve - current state and changes in species composition over the past 100 years. Pol. J. Natur. Sci. 27 (2): 135-150.

Łubek A. 2012b. Nowe dane o interesujących gatunkach porostów z Gór Świętokrzyskich i terenów przyległych. Fragm. Flor. Geobot. Polonica 19 (1): 125-135.

Łubek A., Cieśliński S. 2004. Atlas of lichens and lichenicolous fungi in the Świętokrzyski National Park. Acta Mycol. 39 (2): 173-252.

Olech M., Kiszka J. 1999. Agonimia tristicula (Nyl.) Zahlbr. (In:) S. Cieśliński, W. Fałtynowicz (eds). Atlas of the geographical distribution of lichens in Poland 2: 7-11. W. Szafer Institute of Botany, Polish Academy of Science, Kraków.

Sérusiaux E., Diederich P., Brand A.M., van den Boom P. 1999. New or interesting lichens and lichenicolous fungi from Belgium and Luxembourg. VIII. Lejeunia 162: 1-95.

Szczepańska K. 2008. Antropogeniczne przemiany bioty porostów Masywu Śnieżnika i Gór Bialskich. Acta Bot. Siles., Monogr. 4: 1-291. 
Smith C.W., Aptroot A., Coppins B.J., Fletcher A., Gilbert O.L., James P.W., Wolseley P.A. 2009. The lichens of Great Britain and Ireland. The British Lichen Society, London, $1046 \mathrm{pp}$.

Śliwa L. 2010. Contribution to the lichen biota of the Pogórze Wiśnickie foothills (Carpathians). Acta Mycol. 45 (2): 219-230.

Vězda A., Liška J. 1999. Katalog Lišejníků České Republiky. Institute of Botany, Academy of Sciences of the Czech Republic, Průhonice, 283 pp.

Wirth V., Hauck M., von Brackel W., Cezanne R., de Bruyn U., Dürhammer O., Eichler M., Gnüchtel A., Litterski B., Otte V., Schiefelbein U., Scholz P., Schultz M., Stordeur R., Feuerer T., Heinrich D., John V. 2010. Checklist of lichens and lichenicolous fungi in Germany. Georg August University of Göttingen, Germany. http://www.gwdg.de/ mhauck

\section{Gatunki z rodzaju Agonimia i inne rzadkie porosty w Polsce Środkowej}

\section{Streszczenie}

W pracy przedstawiono osiem gatunków porostów: Agonimia flabelliformis, A. opuntiella, A. tristicula, Bacidina sulphurella, Caloplaca cerina var. chloroleuca, Micarea adnata, M. hedlundii i Porina leptalea, które stwierdzono ostatnio w Górach Świętokrzyskich i ich najbliższym sąsiedztwie. Wśród nich, cztery nie były dotąd znane z tego pasma górskiego i z Polski Środkowej. Są to: Agonimia flabelliformis, A. opuntiella, A. tristicula i Micarea adnata.

Badane materiały zdeponowane są w zielniku Uniwersytetu Jana Kochanowskiego w Kielcach. 